Article

\title{
Interrelation between Eco-Innovation and Intra-Industry Trade-A Proposal for a Proxy Indicator of Sustainability in the EU Countries
}

\author{
Teodoro Gallucci ${ }^{1, *, t,(\mathbb{D})}$, Vesselina Dimitrova ${ }^{2,+(\mathbb{D})}$ and Georgi Marinov ${ }^{2,+}+(\mathbb{B}$ \\ 1 Department of Economics, Management and Law, University of Bari, 70124 Bari, Italy \\ 2 Faculty of Management, University of Economics-Varna, Varna 9002, Bulgaria; \\ vesselina.dimitrova@ue-varna.bg (V.D.); gmarinov@ue-varna.bg (G.M.) \\ * Correspondence: teodoro.gallucci@uniba.it; Tel.: +39-080-504-9086 \\ + These authors contributed equally to this work.
}

Received: 1 October 2019; Accepted: 17 November 2019; Published: 24 November 2019

check for updates

\begin{abstract}
The "innovation-trade" interrelation has been a subject of research for decades. Nowadays, in the context of the growing importance of sustainable development, the role of eco-innovation is essential for promoting a rapid economic growth in each country. In this sense, eco-innovation influences the level of intra-industry trade stimulating international trade to adopt environmentally-friendly technologies. In general, the evaluation of eco-innovation in EU countries is done through indicators of their degree of performance and their impact on the welfare of nations. Using Eurostat data and WITS (World Integrated Trade Solution) database for the period 2010-2018, the authors of this paper give empirical evidence of a linkage between the two indicators. The Grubel-Lloyd index is selected as an appropriate tool to show that socio-economic performance has a significant weight in eco-innovation scoreboard measurement. The results confirm that intra-industry trade of each EU country is closely related to the level of its eco-innovation index. To our knowledge, this is the first attempt to test for such a type of interrelation and to show that by verifying the usefulness of eco-innovation performance in EU countries through an intra-industry trade indicator (IIT) such as the Grubel-Lloyd index.
\end{abstract}

Keywords: eco-innovation; Grubel-Lloyd index; intra-industry trade; European Union countries

JEL Classification: D91; L10; O10; O57; P20; P52

\section{Introduction}

Eco-innovation is a concept of great importance to business and policy makers, which covers many innovations of environmental benefit [1]. Eco-innovation is defined as any form of innovation aiming at a significant and demonstrable advancement towards the goal of sustainable development, through reducing the impacts on the environment or achieving an efficient and responsible use of resources, including both intended and unintended environmental effects from innovation, as well as not only environmental technology but also processes, systems and services [2]. Eco-innovation is becoming an indispensable tool for stimulating efficiency in the use of resources. However, to promote eco-innovation initiatives, the new economic investment needed at the local and national level is the support for research, information and education of both businesses and consumers. All the aforementioned actions can contribute towards the overcoming of the main barriers to eco-innovations by achieving an efficient use of resources, by increasing investments and by ensuring that all relevant policies influence the efficiency of resources in a balanced manner. Currently the European Union recognises eco-innovation as the main driver for sustainable development, 
and for this reason it has developed a specific indicator that can measure the level of eco-innovation: the Eco-Innovation Scoreboard (Eco-IS). This tool, developed by the European Eco-Innovation Observatory (EIO), allows for the evaluation of the performance of European countries and the comparison between the results obtained, outlining strengths and weaknesses. The Eco-IS consists of 16 indicators that are grouped into five separate components: (1) eco-innovation inputs (R\&D appropriations, staff and researchers and green investments in early stages); (2) eco-innovation activities (companies that have implemented innovation activities aimed at reducing material and supplying energy per unit of output); (3) eco-innovation output (measured through patents, publications and media coverage); (4) environmental results (i.e., the benefits to the environment assessed with reference to the "productivity" of materials, energy and water, together with the "intensity" of greenhouse gas emissions); and (5) socio-economic results (based on performance data of "eco-industries", including those relating to exports, employments and turnover). Obviously, the assessment of eco-innovation results is a set of different indicators. This creates opportunities for new interrelations or impact assessments. On the one hand, improving the quality of technology in the field of ecology is associated with increased income, with the growing turnovers. On the other hand, economic progress based on environmental improvement is unthinkable without the openness of the economy to trade, exchange or investment. In both cases, the cooperation is an encouraging trade policy instrument. Trade cooperation between European Union Member States is based mainly on the intra-industry trade (IIT) [3]. IIT takes place when goods from the same sector are traded in both directions. Thus, the more similar two countries are, the more their trade develops towards IIT. Spulber (2008) [4] counted intra-industry trade as one of the most important properties of technological progress in international trade, as the expected variety of goods traded in equilibrium increases when innovative technology trade increases, thus the countries draw benefits from intra-industry trade [4]. IIT in intra-regional trade has higher increases than that in inter-regional trade (inter-industry trade is defined as trade between two countries where the goods are from different sectors). This situation is valid for EU countries and comes as a consequence of the European integration process [5].

In the last decades, IIT has also been used for other purposes. For measuring eco-innovations, no single method or indicator is likely to be sufficient. In this paper, we discuss the role of the IIT as an alternative indicator for eco-innovation performance in EU countries. The relationship between trade and the environment, and the role of IIT have become increasingly important. In the literature, it is reported that the growth in international trade is characterised by intensive pollution [6]. The main role of the Grubel-Lloyd Index is to validate and verify if there is intra-industry trade or no inter-industry of a particular product among countries. In our paper, the authors validate and verify whether the Grubel-Lloyd Index is a proxy indicator of the eco-index. Despite the widespread view over the years, the description of the IIT measures has had little effect on the environment; the sustainability efforts of modern society require that a new evidence and literature approach be explored. Our study has investigated the linkages between the eco-innovations and the magnitude in intra-industry trade between EU countries for the period 2010-2018. Our goal is to verify the validity of the eco-index through another one, using a reliable and well-established index such as the Grubel-Lloyd index. We adopted the idea to promote the alternative usage of an old and well known index as the Grubel-Lloyd index, the use of which would not create additional obstacles for researchers. The authors' thesis is that the Grubel-Lloyd index is applicable to all sectors, whether or not they pollute the environment. The interrelation between the eco-innovation index and intra-industry trade can gather more information about sustainability and make credible and transparent policy-making decisions about the eco-innovative future policy of each country. For this purpose, we used the Grubel-Lloyd index as a measure of IIT. The paper is organised as follows: Section 2 describes the existing relevant literature. Section 3 provides stylised facts on the eco-innovation index by Eurostat for the period 2010-2018, by country and by periods. We present the Grubel-Lloyd indexes calculated on data from WITS (COMtrade) database, split on SITC Revision 1, one-digit ("Section") and two-digit 
("Division") per year and per country. Finally, an empirical evidence of the linkage between the eco-innovation index and the average Grubel-Lloyd values for different years, is presented.

\section{Literature Review}

Links between trade and sustainability naturally draw from international trade theory [7]. Trade may increase pollution and in the same time trade restrictions can reduce pollution. A weakening of environmental policy will increase a country's net export of polluting goods and will help domestic firms to compete with their foreign rivals. According to the Porter hypothesis, the environmental regulation stimulates technological innovation and thereby has positive effects on both the economy and the environment [8]. International trade has always been considered as a channel for transfer of technology from industrial to relatively less developed countries $[9,10]$. The development of the sustainability concept over the last decades has also made its requirements on trade indexes. The Heckscher-Ohlin-Samuelson (HOS) model is the natural starting point for exploring sustainability. In 1975, Grubel and Lloyd published a paper which stimulated multiple studies in the field of intra-industry trade (IIT). The concept of the authors is based on the HOS model for similar factor endowments and the increasing level of integration between European countries. Over time, the index has developed further to encompass the influence of factors such as trade costs, investment costs, and production [11]. Furthermore, it has become necessary to calculate indicators that reflect the ecological state of each or group of countries in terms of their technological progress and trade policy. Since the seminal Grubel and Lloyd paper (1975) [12], a vast literature on IIT has emerged (for reviews see Ambroziak (2012) [13] and Greenaway and Milner (2005) [14]). Vertically differentiated IIT models step on various versions of the classical Heckscher-Ohlin model, while horizontally differentiated IIT is modelled mostly under monopolistic competition theories, initiated by Dixit and Stiglitz in 1977 [15]. Vertical IIT is the dominant type of trade [16]. For example, for Europe [17], Fontagne et al. investigated in 1998 the nature of trade flows for 1980-1994, demonstrating that there exists a positive link between vertical IIT and horizontal IIT, and that vertical IIT strongly predominates [17]. Different studies demonstrate the effects of levels of aggregation on IIT indexes, emphasising the disentangling of vertical and horizontal intra-industry trade as a great step forward [18]. These studies have the potential to be a basis for the development of eco-innovative techniques and other environment sensitive innovations. Only recently, there have been attempts to specifically measure eco-innovations. The main problem with eco-innovations is their multifaceted nature, therefore multiple approaches have been proposed. As emphasised in Arundel (2009) [1], no single method or indicator is likely to be sufficient to measure eco-innovation. The most widely known are the results of the MEI project (Measuring Eco-Innovation) of the EU and the OECD workshop on greening regional trade agreements.The MEI classification of eco-innovations is: environmental technologies, organisational innovation, product and service innovation, green system innovations. Measuring has been proposed applying survey analysis, patent analysis, and digital and documentary source analysis [19]. Recent studies by Cherniwchan in 2017 and Cherniwchan et al., also in 2017, focus on developing a theory on the links between trade and environment $[20,21]$. Trade as an indicator for eco-innovation has been used only in limited areas-“"Eco-industry, its size, employment, perspectives, and barriers to growth in an enlarged EU" made for DG Environment in 2006 [22] represents an information guideline about exports and imports in selected eco-industry sectors. A crucial question is whether trade in polluting goods is intra-industry, or is driven by comparative advantage. There is little evidence that polluting goods production has shifted towards low-income countries due to trade liberalisation, but there is some evidence that exporters are cleaner than other firms.The inclusion of eco-innovations into the scope of intra-industry trade (IIT) research helps to expand the scope of study of both international trade and intranational trade. There is vast literature on trade liberalisation and the environment, with some publications focusing on IIT. Over the years, different authors have been discussing the interrelation between eco-innovations and intra-industry trade in search of better environmental management solutions for countries or regions. However, the usefulness of a 
specific index as a precise and accurate one has not been calculated. Therefore, the views of some authors closest to the topic of this study are presented. According to J. Roy (2017) [6], the empirical examination of IIT and the environment is overdue and/or relatively unexplored. The increasing interest in greenhouse gas emissions, energy consumption, pollution-intensive industries, etc. over the last years has determined the growing interest in the ecological impact-IIT demand relationship. In the literature, there has been a discussion on trans-border pollution [23,24], but the centre of the debate was around the North-South division. Aralas and Hoehn's analysis of 2010 [25] suggests that greater openness to trade or increased liberalisation of trade leads to lower levels of emissions and therefore is beneficial to the environment.The deepening European economic integration fosters IIT, especially in Eastern European countries, where the existence of fluctuations in IIT indexes is quite evident [26]. Other studies are linked with the attempt of modelling the optimal tax policies and policy reforms in the presence of trans-border pollution [27], as well as studies of the optimal subsidies issue [24]. Using the data of the Environmental Performance Index of the World Bank and the UN Commodity Trade Database of UN Comtrade for more than 200 countries, Roy (2017) concluded that IIT is typically characterised by a positive impact on the environment. IIT is undoubtedly more pro-environment than overall trade. Fung and Maechler (2007) [28] found that the impact depends on the nature of pollution (local, transboundary or global) and on the type of the country which liberalises trade; accordingly, the environmental effects are not necessarily negative. Benarroch and Weder (2006) [29] in their overview also found that increased output need not come at the cost of a higher pollution. Jo et al. (2015) [30] also considered the positive linkage between eco-innovation and technologies as a motivation for trade and socio-economic development. If eco-innovation incorporates new technologies in favour of the market, for example green products, the economy of each country evolves thanks to sustainable industrial systems. The authors called this effect "the ripple effect for sustainability" [30]. The report of Sweden's Globalisation council (2009) [31] also studies the effects of trade on the environment. Some evidence of this report suggests that trade and growth can exacerbate other measures of environmental degradation, particularly $\mathrm{CO}_{2}$ emissions (carbon dioxide). In environmental policy studies, there is some evidence that tighter environmental standards at home can lead to less emissions abroad [32]. At the same time, it is emphasised that no single country can address global environmental problems on its own, due to the freerider problem. Thus, environmental policy requires international cooperation, and international trade puts significant downward and upward pressure on ecological issues. To summarise, environmental issues in connection with IIT have rarely been studied. There are some attempts to use IIT as a proxy for other indicators-i.e., measures for the change of IIT are mainly used as indicators for labor adjustment [33]. This has made the current research relevant and useful to researchers in both the eco-innovation and trade area of studies.

\section{Methodology and Data}

The intention of this study was to make a proof-of-concept of the possibility to use the IIT as a proxy for eco-innovation measures. The methodology includes the following steps. Firstly, we collected data from Eurostat for the eco-indexes (Eco-Innovation Scoreboard, Eco-IS) for all EU countries. We utilised the Eurostat eco-innovation index to show how well each individual Member State performs in eco-innovations, as compared to the EU average. As the EU-28 average index is equal to 100, the value for each country depends on the relevant components(eco-innovation input, eco-innovation activities, eco-innovation output, environmental results and socio-economic results). Based on these data, we calculated a standard deviation of eco-indexes per country and per year. The degree of variation of the index allows predicting which countries would be potentially problematic in their eco-innovation performance. Other necessary data for our research are the import-export data (in thousands of dollars) from WITS (COMtrade) database of UN for the EU-28 countries. We utilised SITC Revision 1 classification, with one-digit level of aggregation ("Section") per year and per country, because it represents the most recognisable and used nomenclature of goods. This nomenclature includes the following groups: food and live animals, beverage and tobacco, crude materials and fuels, mineral 
fuels and relevant materials, animal and vegetable oils and fats, manufactured goods classified chiefly by material, machinery and transport equipment, miscellaneous manufactured goods, commodities and other (not class) goods. All data were selected for the period 2010-2018 for the above-mentioned 10 sectors. Further, we extended the research for two-digit level ("Division"), comprising 60 sectors. In fact, we have a "mirror" database for the trade of each EU country, or in other words one country (Reporter country) has 27 trading partners and each of these partners have counter-standing trade position for this country. Furthermore, in our study, we utilised the classical Grubel-Lloyd formula, according to the data for the export of each EU country:

$$
G L=1-\frac{\sum_{k=1}^{n}\left|X_{k}-M_{k}\right|}{\sum_{k=1}^{n}\left(X_{k}+M_{k}\right)}
$$

where $X_{k}$ and $M_{k}$ are respectively the export and the import of the $k$-th sector.

We utilised the Grubel-Lloyd index as a measure of proximity in the countries' technology levels. Values closer to 1 indicate a bigger share of intra-industry trade (IIT) between countries, and vice versa. Intra-industry trade, also called two-way trade, consists of simultaneous import and export of products (including assemblies, subassemblies and components) coming from the same industry, which are close substitutes in the sphere of consumption, production, or in both areas [12].

The first IIT index was proposed by Balassa (1966) [34], later the major developments were made by Grubel and Lloyd (1975) [12], which is the most important contribution in the area. During the years, different authors, such as Aquino in 1978 [35], Henao-Rodrigez et al. in 2016 [36], Brulhart in 2009 [37], Greenaway in 1983 [38], Hamilton and Kniest in 1991 [39], Siggel in 2006 [40] and Glejser, Goossens and Eede in 1982 [41], made good overviews of measurement issues of IIT. When the Grubel-Lloyd index (GL) varies to -, it indicates pure inter-industry trade and when the index varies to 1 , it indicates pure intra-industry trade. We calculate the average meaning of the GL indexes per country, per year. The average meaning represents a value for the country as a whole, thus the trade strengths with a specific commodity are eliminated (presumably, each country has its own natural, socio-economic or other advantages). The next step of our study was to make a regression of the average values of GL indexes with the eco-indexes in order to search for $p$-values $<0.05$ in the ordinary least squares model (OLS). $P$-values show whether there is an interrelation between the values of the GL index and the eco-index. If there is an interrelation, we assume that we can use the GL rather than the eco-index, because it shows the eco-index validity. In this sense, the level of intra-industry trade between countries coincides with their ecological orientation. The more developed countries are expected to have more predominant intra-industry trade (IIT), and vice versa. IIT is a suggestive hint for the degree of technological development of the countries and acts also for a driver of their environmental development. We observed also $R^{2}$ value to be equal to or greater than 0.10, as suggested by Falk and Miller in 1992 [42]. The final step of our study was the clusterisation process, which served for grouping of countries and offered an initial benchmark for their eco-innovation level. On the basis of the Eco-Scoreboard (Eco-IS) database, we positioned the countries both in space ( $28 \mathrm{EU}$ countries in the 8-dimensional space, according to the number of years relevant to this study) and in time (9 years in the 28-dimensional space, according to the number of countries). The purpose of the clusterisation was to find out whether the EU-28 countries differ in their environmental progress per year. Through the calculations made for the period 2010-2018, we prove the existing interrelation between eco-innovation and technological level in the EU-28 countries, as well as analyse the interaction between the two utilised indexes.

\section{Results}

To illustrate the groups of countries within the EU, we start with two dendrograms which represent the eco-innovation index of the 28 Member States of the European Union. The first dendrogram features two sub-clusters that outline the differences in eco-innovation levels in Europe (Figure 1). In clusterising the countries per values of the index in periods, the "East-West" division 
becomes very clearly visible. East European countries have traditionally less eco incentives, and thus the values of the eco-innovation index are lower in general. Thus, the situation for the 1990s, when the East European countries did not participate in international trade and generally lacked incentives, continues to be a particularity 20-30 years later. Environmental consequences are reminiscent of the situation in West European countries one or two generations ago [43].

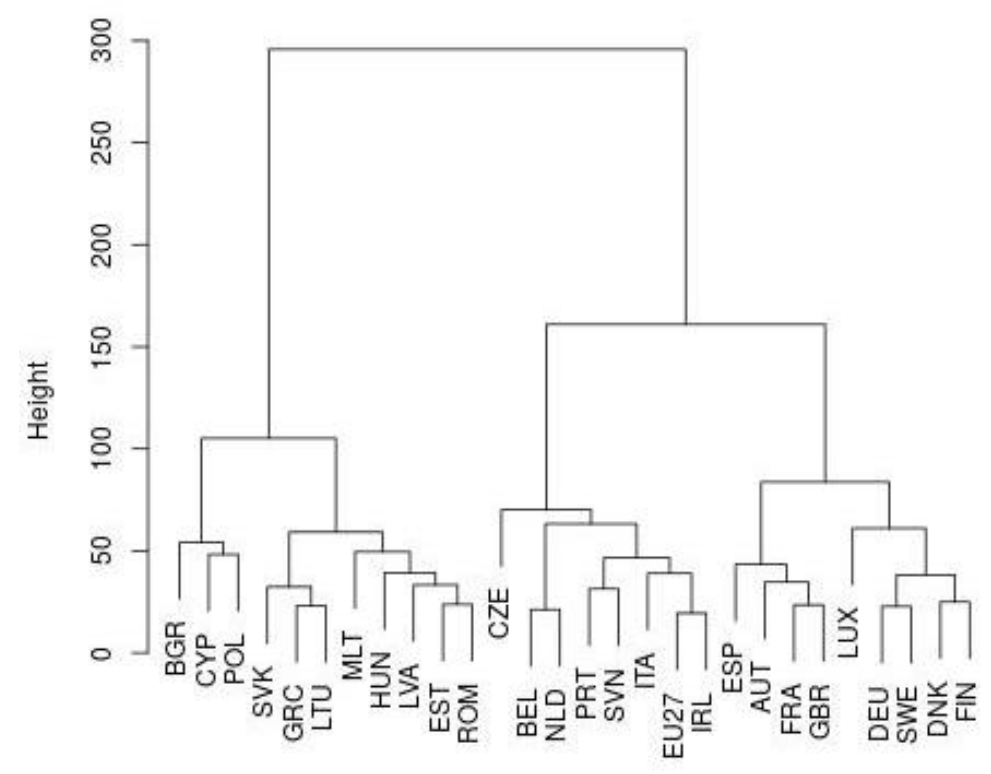

Figure 1. Eco-innovation levels in EU, 2010-2018. Source: Own calculations based on Eurostat data.

By observing the clusterisation diagram (Figure 2) of the eco-innovation index, with the clusterisation made across the countries' dimension, we can also clearly distinguish between the two halves of the period-2010-2013, and 2014-2018, respectively. The main deviations are in 2010 and in 2013, as the first one can be related to the global financial crisis and the second with the recovery from the effects of the financial crisis including the delays in investing in eco-innovations. The clusterisation is in line with findings of other studies [44] that, during a crisis, the part of productivity growth which comes as a result of eco-innovations is reduced.

Our findings show that splitting the clusterisation in two-i.e., for 2010-2013 and 2014-2018-does not change the groups of countries significantly. Countries do not move substantially between sub-clusters, they tend to remain in their initial places in general.

The clusterisation diagrams (available on demand) of the eco-index for the EU countries show that countries such as Germany, Sweden and Finland in the periods 2010-2013 and 2014-2018 sustained their levels of the index. The eco-index values for those countries, which traditionally invest in eco-innovations, are also high. The comparison for the same two periods of the eco-index values of countries such as Bulgaria, Romania and Croatia shows instability and low levels, which is linked to the low investment in eco-innovation in these countries.

Further, we considered the standard deviations of the index, per country (see Figure 3).

The highest fluctuation of the value is for Bulgaria, followed by other relatively poor countries. The lack of experience in eco-innovation activities can be a plausible explanation for the relatively high standard deviation of the index. The lowest values are observed in the most developed countries-Germany and the Scandinavian countries—where the eco-oriented policies have been applied for many decades.

Next, we continue with the Grubel-Lloyd index. 


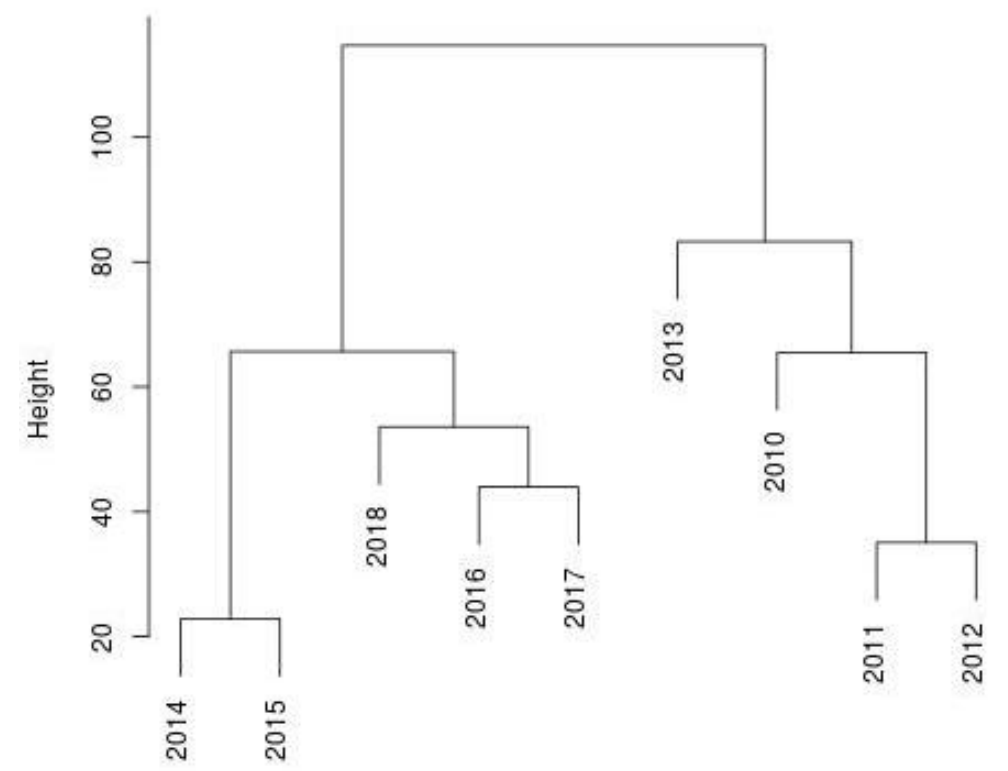

Figure 2. Eco-innovation levels in EU, by period. Source: Own calculations based on Eurostat data.

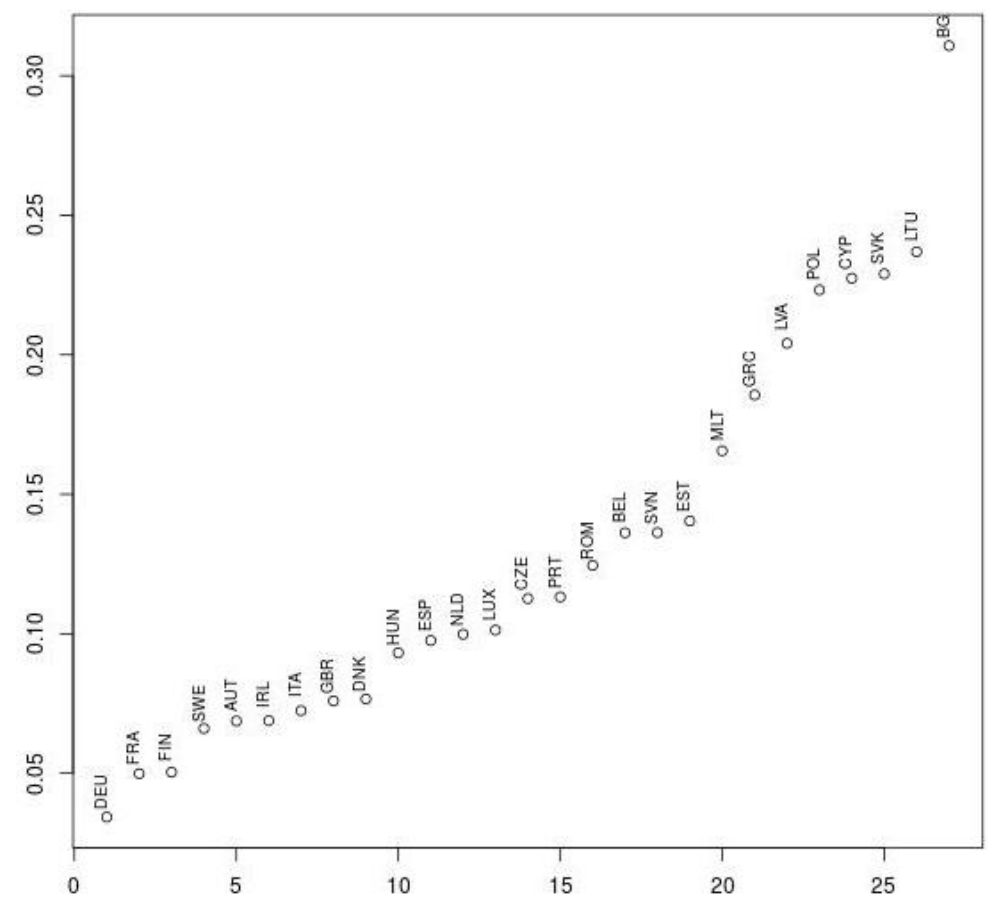

Figure 3. Standard deviations of the eco-innovation index. Source: Own calculations based on WITS data.

We wanted to check the fundamental ability of IIT to be a proxy for the eco-innovations, therefore we used data for the EU countries. In this way, we wanted to handle the "data existence and quality" problem-for many countries, the data for eco-innovations are either unavailable or incomplete, or both.

We consider EU data suitable for our study, because of the relative comparability between the country data and the relatively wide sample, with regions including countries of different technology, climate and income. 
For our purpose, the data for 2010-2018 were retrieved from the WITS (Comtrade) database. We took exports and imports in USD, mirror data for the 28 countries, split on SITC Revision 1, one-digit ("Section") and two-digit ("Division") level of aggregation. We utilised data for 2010-2018, i.e., for one-digit 2017 data, we took 7547 export/import pairs, for 2016, 7560 pairs, etc. We consider such division of data as informative enough, since our goal is to make a "proof-of-concept" study. Furthermore, the literature on VIIT vs. HIIT (vertical vs. horizontal IIT) suggests that HIIT is a relatively rare case, even between EU countries, and the "Section" division captures VIIT quite well.

We calculated the bilateral GL-indexes and also the average values per country per year (Table 1 represents the calculations for 2017 only; others are available on request from the authors). The data (Table 1) confirm that IIT is large for the trade between countries with relatively similar profiles (income per capita, consumers with similar demand, etc.). For example, Estonian GL-indexes have relatively big values for Finland (0.72, similar language and traditions) and for several countries with similar (totalitarian) past and income-Bulgaria (0.78), Romania (0.74), Lithuania (0.64), Latvia (0.69) and Portugal (0.61)—unlike for Luxembourg (0.05).

Table 1. IIT Grubel-Lloyd indexes for 2017 EU-28. Source: Own calculations based on WITS data.

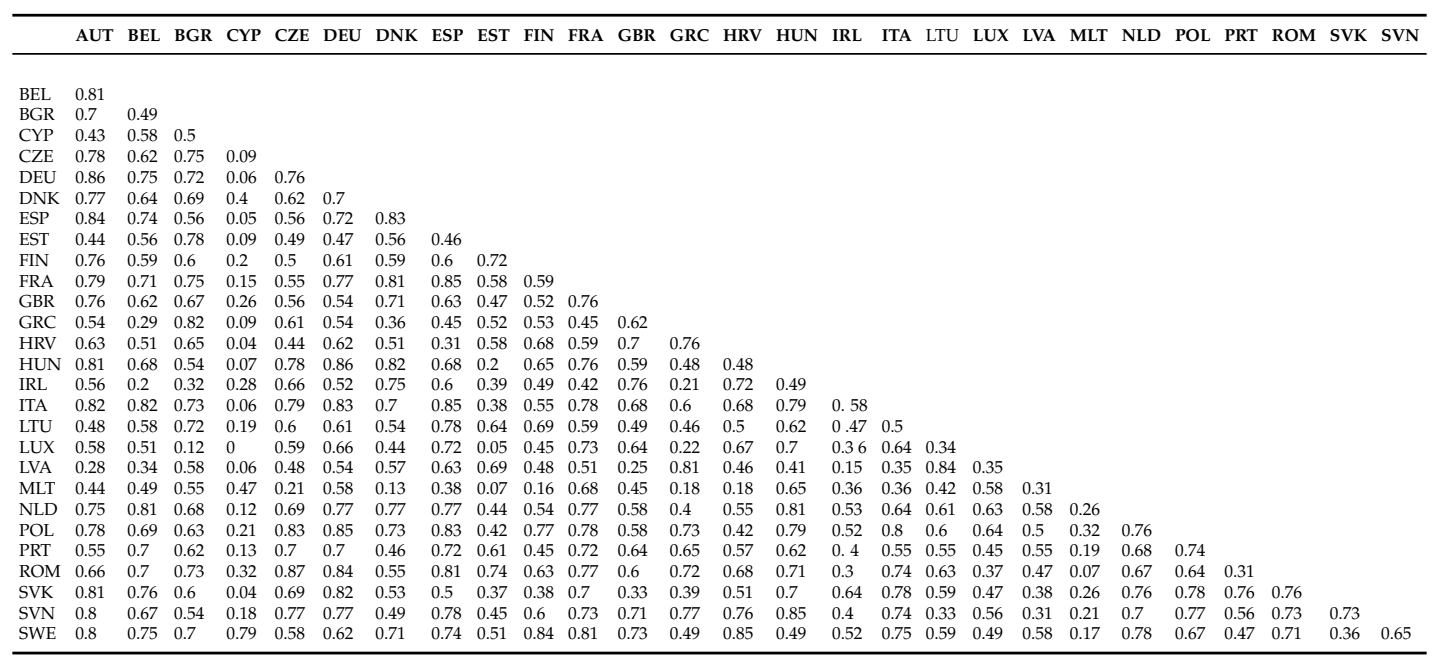

Table 2 shows the average of the GL-index by country for the period 2010-2018. First, an index was calculated for each partner country, and then average values for each country were calculated. This gives a clearer picture of the values of intra-industry trade in EU countries.

The highest average values of the indexes are of Germany (0.68-0.70, Table 2).

Our next step was to search for linkages between the GL-index and the eco-innovations index. We used simple regression (ordinary least squares, OLS) because we aimed to obtain robust and easy understandable and replicable results.

Year by year regressions of the eco-index values on the average Grubel-Lloyd values (for each year we regress the GL index on the eco-index) have significant results for many of the years studied-there is a link between GL and the eco-index.

In the standard OLS models with an intercept, the $p$-values for the slope coefficients are significant at $5 \%$ in 2010, 2013,2014, 2015, and 2018; for 2012, the coefficient is significant at $10 \%$ level with SITC one-digit and at $5 \%$ with SITC two-digit data. More specifically, the GL-index seems to be dependent on eco-innovation. In models without an intercept, $p$-values are very close to zero, indicating an even stronger interdependence. Our results confirm that for the bigger part of the years (2010-2018) $R^{2}$ values are greater than 0.16 and the variance explained of our particular endogenous construct is deemed adequate. 
Table 2. Average GL-indexes, 2010-2018, EU-28. Source: Own calculations based on WITS data.

\begin{tabular}{ccccccccccccccc}
\hline Year & AUT & BEL & BGR & CYP & CZE & DEU & DNK & ESP & EST & FIN & FRA & GBR & GRC & HRV \\
\hline 2010 & 0.65 & 0.58 & 0.51 & 0.34 & 0.62 & 0.69 & 0.59 & 0.59 & 0.45 & 0.52 & 0.64 & 0.59 & 0.45 & 0.48 \\
2011 & 0.66 & 0.57 & 0.52 & 0.41 & 0.61 & 0.69 & 0.57 & 0.59 & 0.45 & 0.54 & 0.64 & 0.60 & 0.48 & 0.48 \\
2012 & 0.64 & 0.58 & 0.52 & 0.36 & 0.62 & 0.69 & 0.60 & 0.60 & 0.43 & 0.54 & 0.64 & 0.58 & 0.45 & 0.48 \\
2013 & 0.64 & 0.58 & 0.54 & 0.35 & 0.63 & 0.69 & 0.59 & 0.61 & 0.45 & 0.55 & 0.65 & 0.59 & 0.47 & 0.47 \\
2014 & 0.64 & 0.59 & 0.54 & 0.36 & 0.64 & 0.69 & 0.61 & 0.63 & 0.42 & 0.56 & 0.66 & 0.59 & 0.46 & 0.48 \\
2015 & 0.63 & 0.57 & 0.56 & 0.35 & 0.61 & 0.68 & 0.59 & 0.63 & 0.46 & 0.57 & 0.66 & 0.57 & 0.46 & 0.51 \\
2016 & 0.65 & 0.59 & 0.60 & 0.36 & 0.64 & 0.70 & 0.59 & 0.65 & 0.48 & 0.58 & 0.67 & 0.61 & 0.48 & 0.53 \\
2017 & 0.67 & 0.61 & 0.61 & 0.32 & 0.67 & 0.70 & 0.60 & 0.67 & 0.52 & 0.60 & 0.67 & 0.61 & 0.51 & 0.56 \\
2018 & 0.69 & 0.61 & 0.63 & 0.35 & 0.66 & 0.72 & 0.63 & 0.67 & 0.52 & 0.60 & 0.70 & 0.60 & 0.49 & 0.54 \\
\hline & HUN & IRL & ITA & LTU & LUX & LVA & MLT & NLD & POL & PRT & ROM & SVK & SVN & SWE \\
\hline 2010 & 0.57 & 0.37 & 0.63 & 0.46 & 0.41 & 0.42 & 0.43 & 0.56 & 0.63 & 0.51 & 0.58 & 0.55 & 0.55 & 0.60 \\
2011 & 0.59 & 0.37 & 0.64 & 0.44 & 0.42 & 0.42 & 0.35 & 0.57 & 0.64 & 0.53 & 0.60 & 0.58 & 0.57 & 0.58 \\
2012 & 0.60 & 0.39 & 0.63 & 0.47 & 0.39 & 0.41 & 0.40 & 0.58 & 0.64 & 0.54 & 0.56 & 0.57 & 0.57 & 0.60 \\
2013 & 0.59 & 0.43 & 0.62 & 0.52 & 0.41 & 0.42 & 0.39 & 0.59 & 0.64 & 0.55 & 0.58 & 0.57 & 0.58 & 0.62 \\
2014 & 0.62 & 0.46 & 0.63 & 0.52 & 0.42 & 0.39 & 0.33 & 0.58 & 0.65 & 0.57 & 0.58 & 0.58 & 0.60 & 0.61 \\
2015 & 0.59 & 0.44 & 0.64 & 0.53 & 0.42 & 0.43 & 0.34 & 0.59 & 0.65 & 0.57 & 0.62 & 0.56 & 0.59 & 0.61 \\
2016 & 0.62 & 0.48 & 0.65 & 0.55 & 0.45 & 0.44 & 0.37 & 0.61 & 0.66 & 0.57 & 0.61 & 0.58 & 0.61 & 0.61 \\
2017 & 0.65 & 0.47 & 0.67 & 0.55 & 0.46 & 0.48 & 0.40 & 0.60 & 0.67 & 0.58 & 0.63 & 0.60 & 0.63 & 0.66 \\
2018 & 0.66 & 0.48 & 0.67 & 0.61 & 0.47 & 0.48 & 0.39 & 0.62 & 0.67 & 0.58 & 0.64 & 0.64 & 0.62 & 0.64 \\
\hline
\end{tabular}

$p$-values of the slope coefficient are represented in the following Table 3.

Table 3. OLS results— $-p$-values of slope coefficients, 2010-2018, EU-28. Source: Own calculations based on WITS data.

\begin{tabular}{cccccccccc}
\hline Year & $\mathbf{2 0 1 0}$ & $\mathbf{2 0 1 1}$ & $\mathbf{2 0 1 2}$ & $\mathbf{2 0 1 3}$ & $\mathbf{2 0 1 4}$ & $\mathbf{2 0 1 5}$ & $\mathbf{2 0 1 6}$ & $\mathbf{2 0 1 7}$ & $\mathbf{2 0 1 8}$ \\
\hline SITC one-digit & 0.035 & 0.246 & 0.079 & 0.033 & 0.026 & 0.026 & 0.181 & 0.107 & 0.01 \\
SITC two-digit & 0.0125 & 0.11 & 0.041 & 0.019 & 0.0225 & 0.0226 & 0.159 & 0.114 & 0.0462 \\
\hline
\end{tabular}

We also calculated the standard deviation (coefficient of variation) of both the GL-indexes and the eco-innovation indexes, in order to explore whether there is a positive link between variances. The average standard deviation for the period, by country, regressed on the standard deviation of the eco-innovation index leads to significant results (F-statistic: 5.46 on 1 and $25 \mathrm{DF}, p$-value: 0.027), $p$-value for the slope coefficient is $0.027(\mathrm{t}=2.306)$. We can claim the existence of a link between both variances, of the GL-index and of the eco-innovation index. Regressing the standard deviation of the eco-innovation index on the average values of the GL-index gives an even more interesting result-a $p$-value of 0.033 (Figure 3).

We argue that the level of the eco-innovation index is closely related to the level of intra-industry trade index. The use of the SITC Rev 1 two-digit level data (more disaggregated data for 60 sectors) only further supports our results, because p-values in the OLS regressions become smaller. In this case, the distinction between the polluting and non-polluting sector does not have a leading role, because it is country-specific and period-specific for each country and not a subject of cross-country analysis. Therefore, the measure for IIT (the GL-index) can be used as a proxy for eco-innovation level. The data for IIT have better availability, thus using this proxy makes sense.

\section{Discussion}

For a long time, the focus on innovations was concentrated on their dynamics in general. Among the large-scale efforts to measure innovation are: the European innovation scoreboard; OECD science technology and industry outlook; UNCTAD world investment report; OECD comparative innovation performance: countries and policies review; Eurostat CIS-2; etc. Specifically for the EU effort, the eco-innovation scoreboard, the calculations made are subject to large fluctuations by country, resulting in variations in the results obtained and might be misleading for the correct level of eco-innovation performance in a particular country. Measuring innovations is reasonable mainly for sustainability purposes, because many normal innovations are de facto eco-innovations. Our study confirms the need for prominent empirical tool to measure eco-innovation. Moreover, the degree of technological development of the countries depends on the degree of their trade exchange. For this reason, an alternative indicator is needed to act as a verifier of the eco-innovation index in order to ensure that this index is a suitable measure. One of the explanations for this fact is that the 
existing data for the eco-innovation index have been available since 2010 (less than 10 observations per country, because it is an annual index, with data for 2010-2018), therefore unit root and co-integration techniques just do not work, even the panel ones-with such data length tests have virtually no power at all. Therefore, we have adopted the strategy to make several OLS regressions for each year in the $\mathrm{N}$ dimension (we have ca. 30 countries). To exclude the possible endogeneity, we make the OLS in the "space" dimension-among countries, for the same year. For this reason, the OLS cannot be considered a basic one, but it is the only applicable in our study (considering the observations in the $\mathrm{T}$ dimension). Therefore, we offer a GL index, exploring carefully the empirical work guided by theory. Our research of EU countries for the period 2010-2018 shows that, due to the interrelation between eco-innovation and intra-industry trade (IIT), the GL index is a proxy indicator for eco-innovation performance across countries. The results of our research show that the GL-index and the eco-index reveal the strengths and weaknesses of each country in terms of eco-innovation and IIT in a similar way. We note that the intra-industry trade, and the simultaneous import and export of similar types of goods or services, determines the level of eco-innovations in all EU countries. The results of the study allow us to also place particular attention to the eco-innovation level by country. It is confirmed that the EU-28 countries are technologically different and the Eastern European countries have a lower degree of environmental progress. Our study confirms some other research results for the European countries: countries with a lower level of socio-economic activity as compared to their supportive environment need to prioritise on using more direct measures such as appropriate technology transfer to promote and increase the eco-innovation activities [30]. Our analysis also argues that the higher is the income in a given country, the higher are the levels of ecological development and IIT. In this context, the eco-innovation is becoming a problematic indicator for lower-income countries because the rising incomes affect environmental quality in a positive way. Our study amplifies the knowledge on some other observations [45] that IIT is linked to FDI inflows, particularly in Eastern European "transition" economies, because the low level of the eco-innovation index in these economies is also due to weak foreign investments in sustainable production and technology. The proposal for a proxy indicator fully corresponds to the eco-innovation mission to realise a new policy learning in Europe, as suggested by Kemp in 2011 [46] and better identification of policy mix and their instruments for sustainable development as mentioned in the platform of the European Sustainable Development Network [47]. Within the EU-28, this indicator can be implemented by the national governments as opportunity measure for successful trade and technological experience.

\section{Conclusions}

In this paper, we argue that trade policy should be assessed in light of the impact on sustainability and sustainable development strategies. The empirical evidence shows that the GL index is more intense among countries with high eco-innovation index, unlike those with a lower eco-index. This result is very important because there is a link between eco-innovations and trade, as demonstrated by Roy in 2017 [6]. For this reason, the adoption of measures aiming at improving the transition to eco-innovation (such as diffusion of green technologies or environmental certification) will improve the intra-industry trade favouring the whole economic performance. Constantini et al. (2017) [48] found that eco-innovations seem to be able not only to directly reduce pollution, but also to foster overall environmental performance via market transactions, both domestically and internationally. In our article, the Grubel-Lloyd Index does not show whether the eco-innovation is an effective way of favouring the transition to a low-carbon sustainable economy, or whether it relates to the degree of environmental pollution or environmental damage differences among sectors (as shown in other recent studies), but it illustrates that eco-innovation can be a driver to incentivise the intra-industry trade without compromising on the increasing greenhouse gas emissions, climate change, land degradation or energy consumption which characterise trade growth. To summarise, the Grubel-Lloyd Index is a proxy indicator of the eco-index. In the centre of our views, is the fact that it is the spread of environmental technologies what matters, and it happens in all sectors, thus a 
division in polluting/non-polluting sectors does not contribute much to the development of our ideas. Moreover, a rigorous sector-by-sector analysis seems for now not to be a feasible task, because of the scarcity of data; even for the EU data exist only for a limited number of countries (see [49]). Therefore, even an indirect measure, such as the one we propose, has the potential to be useful.

These results are strategic for helping to disseminate eco-innovations, and green knowledge among countries. Therefore, identifying clearly specific needs and barriers is a fundamental precondition to fostering the development and transfer of eco friendly technologies [50]. Environmental issues have been discussed in the scope of international trade in general-trade can lead to growth, and therefore to greater environmental awareness [51]. This study shows that the eco-innovation contributes to sustainability as a direct measure, but at the same time it is an incomplete indicator. A trend to investigate "eco-innovation-IIT interrelation" is emerging, because the existing indicators for measuring international trade can no longer be just a neutral mechanism for confirming or rejecting the sustainable welfare. IIT enhances sustainability, but IIT differs for goods and diffusion of innovations due to higher varieties in different countries. Our study helps to enrich the limited volume of empirical studies similar to the present and creates opportunities for new research.

Author Contributions: Introduction: V.D.; Literature review: T.G. and G.M.; Methodology and data: G.M.; Results: V.D., G.M. and T.G.; Discussion V.D., G.M. and T.G.; Conclusions: T.G. and V.D.

Funding: This research received no external funding.

Conflicts of Interest: The authors declare no conflict of interest.

\section{References}

1. Arundel, A.; Kemp, R. Measuring Eco-Innovation; UNU-MERIT: Maastricht, The Netherlands, 2009.

2. EIO. Europe in Transition: Paving the Way to a Green Economy through Eco-Innovation; European Commission: Paris, France, 2012.

3. Łapińska, J. Determinant Factors of Intra-Industry Trade: The Case of Poland and Its European Union Trading Partners. Equilibrium. Q. J. Econ. Econ. Policy 2016, 11, 251-264. [CrossRef]

4. Spulber, D. S. Innovation and International Trade in Technology. J. Econ. Theory 2008, 138, 1-20. [CrossRef]

5. Widodo, T. Modified Grubel-Lloyd index: Intra-industry trade and intra-regional trade in East Asia. In MPRA Paper 77992; University Library of Munich: Munich, Germany, 2009; pp. 1-27.

6. Roy, J. On the environmental consequences of intra-industry trade, J. Environ. Econ. Manag. 2017, 83, 50-67. [CrossRef]

7. Copeland, B.R.; Taylor, M.S. Trade, Growth, and the Environment. J. Econ. Lit. 2004, 42, 17-71. [CrossRef]

8. Frankel, J.A.; Rose, A.K. Is Trade Good or Bad for the Environment? Sorting out the Causality; NBER Working Paper Series N-9201; National Bureau of Economic Research, Inc.: Cambridge, MA, USA, 2002; pp. 2-166.

9. Grossman, G.M.; Helpman, E. Innovation and Growth in the Global Economy; MIT Press: Cambridge, MA, USA, 1991.

10. Jasar, M.; Paul, C.J.M. International linkages and productivity at the plant level: Foreign direct investment, exports, imports and licensing. J. Int. Econ. 2007, 71, 373-388.

11. Egger, H.; Egger, P.; Greenaway, D. Intra-industry trade with multinational firms. Eur. Econ. Rev. 2007, 51, 1959-1984. [CrossRef]

12. Grubel, H.G.; Lloyd, P.J. Intra-Industry Trade: The Theory and Measurement of International Trade in Differentiated Products; Macmillan: London, UK, 1975.

13. Greenaway, D.; Milner, C. What have we learned from a generation's research on intra-industry trade? In Trade Theory, Analytical Models and Development; Jayasuriya, S., Ed.; Edward Elgar Publishing: Cheltenham, UK, 2005; pp.147-160, ISBN 9781843763642.

14. Ambroziak, L. FDI and intra-industry trade: Theory and empirical evidence from the Visegrad countries. Int. J. Econ. Bus. Res. 2012, 4, 180-198. [CrossRef]

15. Dixit, A.K.; Stiglitz, J. Monopolistic competition and optimum product diversity. Am. Econ. Rev. 1977, 67, 297-308. 
16. Aturupane, C.; Djankov, S.; Hoekman, B. Horizontal and Vertical Intra-Industry Trade between Eastern Europe and the European Union. Weltwirtschaftliches Arch. World Econ. 1999, 135, 62-81. [CrossRef]

17. Fontagne, L.; Freudenberg, M.; Peridy, N. Intra-Industry Trade and the Single Market: Quality Matters; Centre for Economic Policy Research: London, UK, 1998.

18. Andresen, M.A. Empirical Intra-Industry Trade: What We Know and What We Need to Know; University of British Columbia: Vancouver, BC, Canada, 2003; pp. 1-60.

19. Kemp, R.; Pearson, P. Final Report MEI Project about Measuring Eco-Innovation; UM Merit: Maastricht, The Netherlands, 2007.

20. Cherniwchan, J. Trade Liberalization and the Environment: Evidence from NAFTA and U.S. Manufacturing. J. Int. Econ. 2017, 105, 130-149. [CrossRef]

21. Cherniwchan, J.; Copeland, B.R.; Taylor, M.S. Trade and the environment: New methods, measurements, and results. Annu. Rev. Econ. 2017, 9, 59-85. [CrossRef]

22. EC. Eco-Industry, Its Size, Employment, Perspectives and Barriers to Growth in an Enlarged EU; DG Environment: Brussels, Belgium; Ernst \& Young: Paris, France, 2006.

23. Copeland, B.R.; Taylor, M.S. Trade and transboundary pollution. Am. Econ. Rev. 1995, 85, 716-737.

24. Kayalica, M.O.; Yilmaz, E. Intra-industry trade and consumption-generated pollution externalities. Yapi Kredi Econ. Rev. 2006, 17, 79-94.

25. Aralas, S.B.; Hoehn, J. Intraindustry Trade and the Environment: Is There a Selection Effect? No. 61367; Agricultural and Applied Economics Association: Milwaukee, WI, USA, 2010.

26. Ito, T.; Okubo, T. New Aspects of Intra-industry Trade in EU Countries. World Econ. 2012, 35, 1126-1138. [CrossRef]

27. Kayalica, M.O.; Kayalica, O. Transboundary pollution from consumption in a reciprocal dumping model. Glob. Econ. J. 2005, 5, 1-16. [CrossRef]

28. Fung, K.C.; Maechler, A.M. Trade liberalization and the environment: The case of intra-industry trade. J. Int. Trade Econ. Dev. 2007, 16, 53-69. [CrossRef]

29. Benarroch, M.; Weder, R. Intra-industry trade in intermediate products, pollution and internationally increasing returns. J. Environ. Econ. Manag. 2006, 52, 675-689. [CrossRef]

30. Jo, J.-H.; Poh, T.W.; Kim, S.; Youn, J.-C.; Park, M.S.; Han, K.J.; Jang, E.K. Eco-innovation for sustainability: Evidence from 49 countries in Asia and Europe. Sustainability 2015, 7, 16820-16835. [CrossRef]

31. Frankel, J. Environmental Effects of International Trade; Expert Report no 31 to Sweden's Globalisation Council; Sweden Globalisation Council: Stockholm, Sweden, 2009; pp. 3-88.

32. Gurtzgen, N.; Rauscher, M. Environmental Policy, Intra-Industry Trade and Transfrontier Pollution. Environ. Resour. Econ. 2000, 17, 59-71. [CrossRef]

33. Lovely, M. E.; Nelson, D. R. Intra-industry trade as an indicator of labor market adjustment. Weltwirtschaftliches Arch. 2002, 138, 179-206. [CrossRef]

34. Balassa, B. Tariff reductions and trade in manufactures among the industrial countries. Am. Econ. Rev. 1966, 56, 466-473.

35. Aquino, A. Intra-Industry Trade: Current Perspectives and Unresolved Issues; Weltwirtschaftliches Archiv: Homer Glen, IL, USA, 1978; Volume 114, pp. 275-295.

36. Henao-Rodríguez, C.; Lis-Gutiérrez, J.-P.; Viloria, A.; Laverde, H. Synthesis of the Indices used to Measure Intra-industry Trade. Int. J. Control Theory Appl. 2016, 9, 427-434.

37. Brulhart, M. An account of global intra-industry trade, 1962-2006. World Econo. 2009, 32, 401-459. [CrossRef]

38. Greenaway, D.; Milner, C. On the Measurement of Intra-Industry Trade. Econ. J. 1983, 93, 900-908. [CrossRef]

39. Hamilton, C.; Kniest, P. Trade liberalisation, structural adjustment and intra-industry trade: A note. Weltwirtschaftliches Arch. 1991, 127, 356-367. [CrossRef]

40. Siggel, E. International Competitiveness and Comparative Advantage: A Survey and a Proposal for Measurement. J. Ind. Compet. Trade 2006, 6, 137-159. [CrossRef]

41. Glejser, H.; Goossens, K.; Eede, M.V. Inter-industry versus intra-industry specialization in exports and imports (1959-1970-1973). J. Int. Econ. 1982, 12, 363-369. [CrossRef]

42. Falk, R.D.; Miller, N.B. A Primer for Soft Modelling, University of Akron, 1st ed.; The University of Akron Press: Akron, OH, USA, 1992.

43. Steenge, A.E. A survey of environmental problems in Eastern Europe. Struct. Chang. Econ. Dyn. 1991, 2, 315-332. [CrossRef] 
44. Garcia-Pozo, A.; Sanchez-Ollero, J.-L.; Ons-Cappa, M. Eco-innovation and economic crisis: A comparative analysis of environmental good practices and labour productivity in the Spanish hotel industry. J. Clean. Prod. 2016, 138, 131-138. [CrossRef]

45. OECD. Intra-Industry and Intra-Firm Trade and the Internationalisation of Production. In Economic Outlook; OECD: Paris, France, 2002; pp. 159-170.

46. Kemp, R. Ten themes for eco-innovation policies in Europe. Surv. Perspect. Integr. Environ. Soc. J. 2011, 4, 1-21.

47. Gjoksi, N. Innovation and sustainable development: Linkages and perspectives for policies in Europe. ESDN Q. Rep. 2011, 6, 3-22.

48. Constantini, V.; Crespi, F.; Marin, G.; Paglialunga, E. Eco-innovation, sustainable supply chains and environmental performance in European industries. J. Clean. Prod. 2017, 155, 141-154.

49. Bleischwitz, R.; Giljum, S.; Kuhndt, M.; Schmidt-Bleek, F. Eco-Innovation-Putting the EU on the Path to a Resource and Energy Efficient Economy; Wuppertal Spezial, No. 38; Wuppertal Institut für Klima, Umwelt, Energie: Wuppertal, Germany, 2009.

50. UNEP. Mainstreaming Eco-Innovation in Sustainable Consumption and Production Policies; UNEP: Nairobi, Kenya, 2017; ISBN 978-92-807-3687-8.

51. Grossman, G.; Krueger, A.B. Environmental Impacts of a North American Free Trade Agreement, The US-Mexico Free Trade Agreement; MIT Press: Cambridge, MA, USA, 1993.

(C) 2019 by the authors. Licensee MDPI, Basel, Switzerland. This article is an open access article distributed under the terms and conditions of the Creative Commons Attribution (CC BY) license (http://creativecommons.org/licenses/by/4.0/). 